\title{
RESEARCH
}

Open Access

\section{Effect of garlic extract, ascorbic acid and nicotinamide on growth, some biochemical aspects, yield and its components of three faba bean (Vicia faba L.) cultivars under sandy soil conditions}

\author{
Magda H. Mohamed', Elham A. Badr ${ }^{1}$, Mervat Sh. Sadak ${ }^{2^{*}}$ (D) and Howida H. Khedr ${ }^{1}$
}

\begin{abstract}
Background: Garlic extract is a highly nutritive value extract; it contains large number of important enzymes and more than 200 biochemical compounds such as antioxidants and vitamins. Ascorbic acid and nicotinamide are considered as antioxidants and also known as growth-regulating compounds that influence different physiological and biochemical processes in plants.

Methodology: A field experiment was conducted in sandy soil during two successive seasons of 2015/2016 and 2016/2017 at Research and Production Station, National Research Centre, El-Nubaria Province, El-Behera Governorate, Egypt. The objective of this investigation was to study the effect of foliar application of garlic extract (5\%), ascorbic acid (200 ppm) and nicotinamide (50 ppm) compared with tap water on growth, some biochemical aspects, yield, yield components and some chemical components of three faba bean cultivars (Vicia faba L, cv., Nubaria-1, Nubaria-2 and Giza-843).

Results: The obtained results showed that Nubaria-1 was superior to Nubaria-2 and Giza-843 in all growth and yield criteria in the growing seasons except plant height was superior in Nubaria-2. Foliar treatment of garlic extract had the superiority effect in all characters of growth and yield and its components, and consequently increased significantly all yield criteria of Nubaria-1 cultivar. Data clearly showed that the effect of different treatments caused marked increases in photosynthetic pigments, indole acetic acid, phenolics, carbohydrate constituents, free amino acids and proline contents of Nubaria 1 cultivar which was sprayed by garlic extract at $5 \%$ followed by nicotinamide and ascorbic acid, respectively.

Conclusions: In general, the current research suggested that garlic extract at $5 \%$ as a foliar application increased the quantity of faba bean cultivars grown under sandy soil conditions. Therefore, garlic extract at the rate of 5\% and Nubaria1 encourage the farmers to use of garlic extract to give promising seed yield under reclaimed sandy soil.
\end{abstract}

Keywords: Faba bean, Cultivars, Garlic extract, Ascorbic acid, Nicotinamide, Yield and yield components

\footnotetext{
* Correspondence: mervat_sh24@yahoo.com

${ }^{2}$ Botany Department, Agricultural and Biological Research Division, National

Research Centre, 33th El- Behooth St., P.O. 12622, Giza, Egypt

Full list of author information is available at the end of the article
}

() The Author(s). 2020 Open Access This article is licensed under a Creative Commons Attribution 4.0 International License, which permits use, sharing, adaptation, distribution and reproduction in any medium or format, as long as you give appropriate credit to the original author(s) and the source, provide a link to the Creative Commons licence, and indicate if changes were made. The images or other third party material in this article are included in the article's Creative Commons licence, unless indicated otherwise in a credit line to the material. If material is not included in the article's Creative Commons licence and your intended use is not permitted by statutory regulation or exceeds the permitted use, you will need to obtain permission directly from the copyright holder. To view a copy of this licence, visit http://creativecommons.org/licenses/by/4.0/. 


\section{Introduction}

Faba bean (Vicia faba L.) is the fourth most important leguminous crop in the world. It is one of the most important food crop for human and animal feed (pigs, horses, poultry and pigeons) (Singh and Bhatt, 2012). Seeds of faba bean contain about 58\% carbohydrate, 26\% protein, $2 \%$ fat, some vitamins (vitamin B1, vitamin B2, vitamin $B 3$, vitamin $B 6$, vitamin $B$ 9, vitamin $C$ and vitamin K) and some minerals (calcium, copper, iron, manganese, magnesium, potassium, selenium, sodium and zinc) (Alghamdi, 2009). So, it is a common breakfast food in Egypt and the best crop which can be used as a green manure and also one of the best bio factory of nitrogen by fixing 130 to $160 \mathrm{~kg} \mathrm{~N} / \mathrm{ha}$ (Hoffmann et al., 2007). Moreover, it is a good source of lysine-rich protein and good source of levadopa (L-dopa) a precursor of dopamine, and it can be potentially used as medicine for the treatment of Parkinson's disease (Singh et al., 2013). Increasing faba bean yield per unit area can be achieved by breeding high yielding cultivars. Significant differences in faba bean cultivars have been shown by many workers (Osman et al., 2010, Bakry et al., 2011 and Khattab et al., 2015). In Egypt, Abou-El-Seba et al. (2016) stated that faba bean cultivars showed highly significant variation of plant height, weight and number of pods/plant, 100-seed weight, seed yield/plant and seed yield. In Baltic, Pluduma-Paunina et al. (2018) concluded that faba bean yield has been significantly affected by varieties.

Cultivation of faba bean in newly reclaimed sandy soil suffers from reduction of productivity due to low water, salinity water and soil, nutrient deprivation and temperature fluctuations. Therefore, we can use some ingredients or natural extracts and antioxidants to avoid those problems and increase plant tolerance to these adverse environmental conditions.

Garlic (Allium sativum) is a highly nutritive value extract; it contains large number of important enzymes and more than 200 biochemical compounds such as antioxidants and vitamins (Mohamed It contains high contents of volatile and sulphur compounds such as aliin, allicin, ajoene, allylpropyl, diallyl, trisulfide, sallylcysteine, vinyldithiines, sallylmercaptocystein and others (Mohamed and Akladious, 2014 and El-Saadony et al., 2017). In addition, garlic is considered as a source of vitamins (especially vitamin B complex and vitamin C), antioxidants, flavonoids and minerals (especially $\mathrm{P}, \mathrm{K}$ and Se) (Pekowska and Skupień, 2009), being even considered a rich source of other non-volatile phytonutrients with important medicinal and therapeutic properties, from which a particular emphasis is given to flavonoids, saponins and sapogenins, phenolic compounds, nitrogen oxides, amides and proteins (Lanzotti et al., 2014).
Ascorbic acid (vitamin C) is one of those antioxidants. Ascorbic acid is an abundant molecule in garlic plants. It has also been shown to play multiple roles in plant growth such as in cell division, cell wall expansion and other developmental processes (El-khayate et al., 2015). It also acts as an antioxidant as it detoxifies $\mathrm{H}_{2} \mathrm{O}_{2}$ which is formed by the dismutation of $\mathrm{O}^{-2}$ (Kasim Wedad et al., 2017).

Nicotinamide is known as a growth-regulating factor that influences many physiological processes such as biosynthesis of enzymes, nucleic acids and proteins and acts as a coenzyme (Hathout, 1995). Nicotinamide (vitamin B3/niacin) is a water-soluble vitamin and a wellcharacterized constituent of the pyridine dinucleotide coenzymes NADH and NADPH, which are involved in many enzymatic oxidations--reduction reactions in living cell (Sadak et al.,2010). Abdel-hamid et al. (2013) showed that there is a significant improvement of physiological and biochemical parameters as well as concentrations of soluble sugars, proline, amino acids and total $N$ and other mineral contents of faba bean plants by nicotinamide. Recently, Sadak (2016) reported that growth, yield components, indole acetic acid (IAA), photosynthetic pigments, total soluble sugars (TSS), free amino acids, proline and phenolic contents are significantly increased by soaking of Pisum sativum L. seeds with nicotinamide at the two dates of sowing. Moreover, Dawood et al. (2019) concluded that nicotinamide and/ or humic acid had a positive effect on growth parameters, photosynthetic pigments, seed yield, and yield components as well as some biochemical constituents of the yielded faba bean seeds.

Therefore, the objective of this study was to compare the effect some foliar application with garlic extract, ascorbic acid and nicotinamide on growth, photosynthetic pigments content, yield and yield components and some chemicals components of three faba bean cultivars.

\section{Materials and methods}

Plant materials and experimental conditions

Two field experiments were conducted at Research and Production Station, National Research Centre, ElNubaria Province, El-Behera Governorate, Egypt, during two successive winter seasons of 2015/2016 and 2016/ 2017 to study the effect of foliar application of garlic extract, ascorbic acid, nicotinamide and tap water (control ) on growth, some chemical constituents, yield and yield components of three faba bean cultivars.

The experiment was arranged in split plot design with three replications where the faba bean cultivars (Nubaria-1 )V1), Nubaria-2 (V2) and Giza-843 (V3)) occupied the main plots, while sub-plots were devoted to foliar application of (garlic extract (P1), ascorbic acid (P2), nicotinamide (P3) and tap water (P0, control)) 
randomly in the subplots. The seeds of faba bean cultivars were obtained from Field Crops Research Institute, Agricultural Research Center, Giza. Seeds were planted on November 17 and 20 in the first and second seasons, respectively. Foliar treatments were sprayed on plant foliage twice during plant growth period at 30 and 45 days after sowing. Some mechanical and chemical analysis of soil samples at $30 \mathrm{~cm}$ depth in experimental sites before soil preparation was determined according to Chapman and Pratt (1978). These analyses are presented in Table 1.

Irrigation was carried out using the modern sprinkler irrigation system where water was added every 5 days. Nitrogen fertilizer as ammonium nitrate $(33.5 \%)$ was added at the rate of $(50 \mathrm{~kg} \mathrm{~N} /$ fed.), while phosphorus fertilizer was applied in the form of calcium super phosphate $\left(15 \% \mathrm{P}_{2} \mathrm{O}_{5}\right)$ at the rate of $200 \mathrm{~kg} / \mathrm{fed}$ and potassium fertilizer was added in the form of potassium sulphate $\left(48 \% \mathrm{~K}_{2} \mathrm{O}\right)$ at the rate of $48 \mathrm{~kg} / \mathrm{fed}$ at seedbed preparation. The normal agronomic practices of growing faba bean were practised till harvest as recommended by Legumes Research Dept. A.R.C., Giza.

Garlic extract (5\%): newly produced garlic cloves were brought. Two hundred fifty grams of these cloves was put in a glass beaker that contains $250 \mathrm{ml}$ of tap water. The beaker was put in a freezer for 1 day to freeze, and then the beaker was taken out of the freezer and left it to thaw. Freezing and thawing were repeated three times. Water was added to a final volume of $1 \mathrm{l}$ before filtering. The final volume of the filtrate was adjusted to 1: 1 before being used (Hanafy et al. 2012). Ascorbic acid $200 \mathrm{ppm}$ and nicotinamide $50 \mathrm{ppm}$ were used.

\section{Data recorded}

After 60 days from sowing, ten randomized plants were selected from each plot to determine the growth parameters plant height $(\mathrm{cm})$, number of branch/plant, number of leaves/plant and leaf area $\left(\mathrm{cm}^{2}\right)$ average area of all leaves on a plant. At harvest time, a random sample of ten plants was taken from each plot to determine plant height $(\mathrm{cm})$, weight of plant(g), number of pods/plants, seed yield/plant and 100 -seed weight (g). Seed yield "kilogram/hectare" was collected from the whole plot and then converted into yield per hectare. 1 ha $=10,000 / 4200$ and fed $=(2.38095$ fed $)$.

\section{Chemical analysis}

Total chlorophyll a and b contents in fresh leaves were estimated using the method of Lichtenthaler and Buschmann (2001). Indole acetic acid content was extracted and analysed by the method of Larsen et al. (1962). Phenolic content was measured as described by Danil and George (1972). Total carbohydrates were determined using phenol-sulphoric acid method as described by Dubois et al. (1956). Total soluble sugars (TSS) were extracted according to Homme et al. (1992). Polysaccarides were calculated by subtracting total soluble sugars from total carbohydrates. Free amino acid and proline were extracted according to (Vartainan et al. (1992), free amino acids were determined with the ninhydrin reagent method (Yemm and Cocking, 1955) and proline content was determined according to Bates et al. (1973).

\section{Statistical analysis}

Analysis of variance technique of MSTATC was used to test the degree of variability between the obtained data. Least significant difference (LSD at 5\%) was used for the comparison between treatment means (Gomez and Gomez, 1984).

\section{Results \\ Growth parameters}

Data in Table 2 show that faba bean cultivars significantly differed in their plant height $(\mathrm{cm})$, number of branches/plant, number of leaves/plant and leaf area $\left(\mathrm{cm}^{2}\right)$ at 60 days after sowing. Nubaria-1 cultivar gives the highest values in all growth parameters compared with the other two cultivars.

Different foliar applications (garlic extract, ascorbic acid and nicotinamide) caused marked and significant increases in all growth parameters as compared with untreated control (P0). Foliar application of Garlic extract caused the highest significant increases of plant height $(\mathrm{cm})$ and leaf area (LA) $\left(\mathrm{cm}^{2}\right)$. Meanwhile, foliar application of ascorbic acid gave the highest significant increase of number of branches and number of leaves/plant.

\section{Yield and its components}

Data presented in Table 3 show the effect of cultivars, foliar applications and their interactions on yield and its

Table 1 Mechanical and chemical analysis of the experimental soil

\begin{tabular}{|c|c|c|c|c|c|c|c|c|c|}
\hline \multicolumn{10}{|c|}{ a. Mechanical analysis } \\
\hline Sand \% & Silt \% & Clay \% & Texture & \multicolumn{2}{|c|}{ Organic matter \% } & $\mathrm{pH}$ & \multicolumn{2}{|c|}{$\mathrm{EC}(\mathrm{mhos} / \mathrm{cm})$} & $\mathrm{CaCO}_{3} \%$ \\
\hline 90.80 & 4.00 & 5.20 & Sandy soil & 0.24 & & 8.66 & \multicolumn{2}{|l|}{0.11} & 5.20 \\
\hline \multicolumn{10}{|c|}{ b. Chemical analysis } \\
\hline \multicolumn{6}{|c|}{ Macronutrients (mg/100 g) } & \multicolumn{4}{|c|}{ Micronutrients (ppm) } \\
\hline N & $P$ & K & $\mathrm{Ca}$ & $\mathrm{Mg}$ & $\mathrm{NNa}$ & $\mathrm{Fe}$ & $\mathrm{Zn}$ & $\mathrm{Mn}$ & $\mathrm{Cu}$ \\
\hline 4.20 & 0.12 & 9.22 & 80.00 & 18.20 & 13.18 & 8.15 & 9.12 & 0.10 & 0.20 \\
\hline
\end{tabular}


Table 2 Effect of cultivars, foliar application of garlic extract, ascorbic acid or nicotinamide and interactions on growth parameters of faba bean plants (data are means of two seasons)

\begin{tabular}{|c|c|c|c|c|}
\hline Treatments & Plant & Number & Number & $\mathrm{LA}\left(\mathrm{cm}^{2}\right)$ \\
\hline Characters & $(\mathrm{cm})$ & $\begin{array}{l}\text { branches/ } \\
\text { plant }\end{array}$ & $\begin{array}{l}\text { leaves/ } \\
\text { plant }\end{array}$ & \\
\hline
\end{tabular}

\begin{tabular}{lllll}
\hline Cultivars & & & & \\
V1 & 103.56 & 2.05 & 41.79 & 16.17 \\
V2 & 99.75 & 1.86 & 40.59 & 14.77 \\
V3 & 92.75 & 1.58 & 34.23 & 13.36 \\
LSD at 5\% & 4.05 & 0.47 & 2.34 & 0.92
\end{tabular}

Foliar application

\begin{tabular}{|c|c|c|c|c|}
\hline PO & 89.83 & 1.54 & 30.56 & 12.77 \\
\hline P1 & 111.25 & 1.78 & 41.97 & 16.15 \\
\hline P2 & 94.50 & 2.12 & 42.79 & 14.27 \\
\hline P3 & 99.17 & 1.88 & 40.17 & 16.08 \\
\hline LSD at $5 \%$ & 3.19 & 0.19 & 3.02 & 0.99 \\
\hline $\mathrm{V} 1_{1}$ & 95.00 & 1.85 & 31.33 & 14.30 \\
\hline P1 & 113.75 & 2.50 & 54.33 & 18.18 \\
\hline P2 & 102.50 & 1.85 & 33.5 & 14.41 \\
\hline P3 & 103.00 & 2.00 & 48.00 & 17.78 \\
\hline V2 & 88.00 & 1.19 & 31.00 & 12.40 \\
\hline P1 & 119.50 & 1.25 & 35.00 & 15.02 \\
\hline P2 & 90.00 & 3.00 & 53.87 & 14.41 \\
\hline P3 & 101.50 & 2.00 & 42.50 & 17.23 \\
\hline PO & 86.50 & 1.58 & 29.33 & 11.62 \\
\hline P1 & 100.50 & 1.60 & 36.57 & 14.92 \\
\hline P2 & 91.00 & 1.50 & 41.00 & 14.00 \\
\hline P3 & 93.00 & 1.65 & 30.00 & 12.90 \\
\hline LSD at $5 \%$ & 5.53 & 0.33 & 5.23 & 1.67 \\
\hline
\end{tabular}

$\mathrm{P} 0=$ spraying with tap water, $\mathrm{P} 1=$ foliar application with garlic extract at $(5 \%)$, P2 = foliar application with ascorbic acid at 200 ppm and P1 = foliar application with nicotinamide at $50 \mathrm{ppm}$

components of faba bean plants. Results indicated that yield and its components were significantly affected by cultivars. Nubaria-1 cultivar significantly exceeded Nubaria-2 and Giza-843 cultivars in plant height $(\mathrm{cm})$, weight of plant $(\mathrm{g})$, number of pods per plant, seed yield per plant $(\mathrm{g})$, weight of 100 seeds ( $\mathrm{g}$ ) and seed yield ( $\mathrm{kg} /$ hectare.)

Yield and its components are significantly affected by the foliar applications with garlic extract, ascorbic acid and nicotinamide. Foliar application of garlic extract was more effective in increasing plant height weight of plant (g), number of pods per plant, seed yield/plant (g), 100seed weight $(\mathrm{g})$ and seed yield ( $\mathrm{kg} /$ hectare) compared with other treatments.

Data presented in Table 3 clearly show that no significant differences on yield and its components of faba bean plant except on the number of pods per plant, seed
Table 3 Effect of cultivars, foliar application of garlic extract, ascorbic acid or nicotinamide and interactions on yield and its components of faba bean plants (data are means of two seasons)

\begin{tabular}{lllllll}
\hline Treatments & $\begin{array}{l}\text { Plant } \\
\text { height } \\
\text { Characters }\end{array}$ & $\begin{array}{l}\text { Weight } \\
\text { of plant } \\
(\mathrm{g})\end{array}$ & $\begin{array}{l}\text { Number } \\
\text { of pods/ } \\
\text { plant }\end{array}$ & $\begin{array}{l}\text { Seed } \\
\text { yield/ } / 100 \\
\text { plant } \\
(\mathrm{g})\end{array}$ & $\begin{array}{l}\text { seeds } \\
(\mathrm{g})\end{array}$ & $\begin{array}{l}\text { Seed } \\
\text { yield } \\
(\mathrm{kg} / \mathrm{ha})\end{array}$ \\
\hline Cultivars & & & & & & \\
V1 & 105.53 & 61.52 & 14.45 & 48.52 & 75.12 & 1133.76 \\
V2 & 103.02 & 59.59 & 13.48 & 46.58 & 73.28 & 1104.67 \\
V3 & 100.29 & 59.61 & 10.27 & 38.91 & 64.27 & 924.98 \\
LSD at 5\% & 2.05 & 1.13 & 0.24 & 0.65 & 0.43 & 105.32
\end{tabular}

$\mathrm{P} 0=$ spraying with tap water, $\mathrm{P} 1=$ foliar application with garlic extract at $(5 \%)$, P2 = foliar application with ascorbic acid at $200 \mathrm{ppm}$ and P1 = foliar application with nicotinamide at $50 \mathrm{ppm}$

yield/plant (g) and seed yield (kg/hectare). Nubaria-1 cultivar treated with garlic extract gave the highest values of plant height $(\mathrm{cm})$, weight of plant $(\mathrm{g})$, number of pods per plant and 100-seed weight (g), meanwhile Giza-843 cultivar treated with tap water gave the lowest values of the same previous characters.

\section{Photosynthetic pigments content and some physiological aspects of faba bean}

Data presented in Table 4 show that there are no significant differences between the tested faba bean cultivars in their Chlo a, Chlo b and total pigments. Foliar applications of garlic extract, ascorbic acid or nicotinamide 
Table 4 Effect of cultivars, foliar application of garlic extract, ascorbic acid or nicotinamide and interactions on photosynthetic pigments, IAA and phenolic contents of faba bean

\begin{tabular}{|c|c|c|c|c|c|c|}
\hline \multicolumn{2}{|c|}{ Treatments } & \multirow{2}{*}{$\begin{array}{l}\text { Chlo-a } \\
\mu \mathrm{g} / \mathrm{g} \mathrm{F}\end{array}$} & \multirow{2}{*}{$\begin{array}{l}\text { Chlo-b } \\
\text { wt }\end{array}$} & \multirow[t]{2}{*}{ Total pigments } & \multirow{2}{*}{$\begin{array}{l}\text { IAA } \\
\mu \mathrm{g} / \mathrm{g} F \mathrm{wt}\end{array}$} & \multirow{2}{*}{$\begin{array}{l}\text { Phenolics } \\
\mathrm{mg} / 100 \mathrm{~g}\end{array}$} \\
\hline & Characters & & & & & \\
\hline \multicolumn{7}{|c|}{ Cultivars } \\
\hline & $\mathrm{V} 1$ & 15.98 & 5.68 & 23.85 & 47.46 & 57.58 \\
\hline & V2 & 16.71 & 6.25 & 25.32 & 66.86 & 54.55 \\
\hline & V3 & 22.18 & 8.15 & 35.53 & 57.95 & 52.47 \\
\hline & LSD at $5 \%$ & NS & NS & NS & NS & NS \\
\hline \multicolumn{7}{|c|}{ Foliar application } \\
\hline & PO & 15.09 & 5.84 & 23.12 & 44.09 & 40.98 \\
\hline & P1 & 20.51 & 7.41 & 33.56 & 60.75 & 53.93 \\
\hline & P2 & 18.97 & 6.84 & 28.43 & 61.79 & 61.13 \\
\hline & P3 & 18.59 & 6.68 & 27.82 & 63.08 & 63.42 \\
\hline & LSD at $5 \%$ & 1.12 & 0.40 & 0.70 & 0.37 & 0.32 \\
\hline \multicolumn{7}{|c|}{ Interactions } \\
\hline & PO & 13.28 & 4.81 & 19.92 & 35.39 & 42.59 \\
\hline \multirow[t]{4}{*}{ V1 } & P1 & 17.68 & 5.79 & 25.75 & 48.64 & 58.39 \\
\hline & P2 & 18.22 & 6.45 & 27.15 & 53.06 & 63.49 \\
\hline & P3 & 14.75 & 5.68 & 22.56 & 52.77 & 65.85 \\
\hline & PO & 14.39 & 5.64 & 22.14 & 53.33 & 41.49 \\
\hline \multirow[t]{4}{*}{ V2 } & P1 & 17.63 & 6.75 & 26.91 & 69.91 & 53.91 \\
\hline & P2 & 16.12 & 6.01 & 24.4 & 70.83 & 59.74 \\
\hline & P3 & 18.69 & 6.61 & 27.84 & 73.39 & 63.05 \\
\hline & PO & 17.6 & 7.08 & 27.3 & 43.39 & 38.86 \\
\hline \multirow[t]{4}{*}{ V3 } & P1 & 26.21 & 9.64 & 48.01 & 63.7 & 49.49 \\
\hline & P2 & 22.59 & 8.07 & 33.75 & 61.48 & 60.18 \\
\hline & P3 & 22.32 & 7.75 & 33.07 & 63.08 & 61.36 \\
\hline & LSD at $5 \%$ & 1.94 & 0.74 & 1.4 & 0.64 & 0.56 \\
\hline
\end{tabular}

P0 = spraying with tap water, P1 = foliar application with garlic extract at $(5 \%)$, $\mathrm{P} 2=$ foliar application with ascorbic acid at $200 \mathrm{ppm}$ and P1 $=$ foliar application with nicotinamide at $50 \mathrm{ppm}$

caused significant increases in chlorophyll $a$, chlorophyll $b$ and consequently total pigments compared with control plants. The best appropriate treatment was garlic extract followed by nicotinamide and ascorbic acid, respectively, compared with untreated control. The highest value of chlorophyll $a$, chlorophyll $b$ and total pigments (26.21, 9.64 and 48.01 , respectively) were obtained by garlic extract treatment of Giza-843 cultivar compared with the other two cultivars.

Table 4 showed that there was no significant difference between cultivars on indole acetic acid and phenolic contents, while foliar spraying with different compounds caused marked increases in indole acetic acid and phenolic contents. Moreover, data indicated that nicotinamide treatment was more effective than other treatments. The interaction between cultivars and the foliar application was significantly effective on the same behaviours. Nubaria- 2 cultivar treated with nicotinamide gave the most positive effect on indole acetic acid than the other interactions, while Nubaria-1 cultivar treated with nicotinamide gave the highest value of phenolic contents.

Table 5 shows that significant differences were observed among cultivars under the study in total carbohydrate\%, total soluble sugars, polysaccharides\%, free amino acids and proline contents of faba bean plants. Nubaria-1 cultivar gave the highest contents of total carbohydrates\% and polysaccharides\%, while Nubaria-2 cultivar recorded the highest value of total soluble sugars and free amino acids. In respect to proline, Giza- 843 cultivar was superior on other cultivars in proline value.

Table 5 Effect of cultivars, foliar application of garlic extract, ascorbic acid or nicotinamide and interactions on carbohydrate constituents, free amino acids and proline contents of faba bean plant

\begin{tabular}{|c|c|c|c|c|c|c|}
\hline \multicolumn{2}{|c|}{ Treatments } & \multirow[t]{2}{*}{$\begin{array}{l}\text { Total } \\
\mathrm{CHO} \%\end{array}$} & \multirow[t]{2}{*}{ TSS\% } & \multirow[t]{2}{*}{$\begin{array}{l}\text { Ploysaccharides } \\
\%\end{array}$} & \multirow[t]{2}{*}{$\begin{array}{l}\text { Free amino } \\
\mathrm{mg} / 100 \mathrm{~g} \mathrm{dr}\end{array}$} & \multirow[t]{2}{*}{$\begin{array}{l}\text { Proline } \\
y w t\end{array}$} \\
\hline \multicolumn{2}{|r|}{ Characters } & & & & & \\
\hline \multicolumn{7}{|c|}{ Cultivars } \\
\hline & V1 & 20.39 & 2.12 & 18.26 & 266.52 & 38.32 \\
\hline & V2 & 18.54 & 2.60 & 15.94 & 343.19 & 51.21 \\
\hline & V3 & 19.98 & 2.32 & 17.66 & 302.10 & 52.67 \\
\hline & LSD at $5 \%$ & 0.14 & 0.05 & 0.17 & 1.18 & 0.66 \\
\hline \multicolumn{7}{|c|}{ Foliar application } \\
\hline & PO & 18.67 & 2.05 & 16.62 & 274.78 & 38.92 \\
\hline & P1 & 19.66 & 2.23 & 17.44 & 306.21 & 45.56 \\
\hline & P2 & 20.11 & 2.35 & 17.76 & 317.69 & 56.84 \\
\hline & P3 & 20.10 & 2.75 & 17.35 & 317.07 & 54.28 \\
\hline & LSD at $5 \%$ & 0.10 & 0.05 & 0.09 & 1.30 & 0.46 \\
\hline \multicolumn{7}{|c|}{ Interactions } \\
\hline & PO & 19.39 & 1.91 & 17.48 & 227.5 & 30.99 \\
\hline \multirow[t]{4}{*}{$\mathrm{V} 1$} & P1 & 20.55 & 2.08 & 18.47 & 276.91 & 35.76 \\
\hline & P2 & 20.79 & 2.12 & 18.67 & 288.39 & 39.69 \\
\hline & P3 & 20.82 & 2.39 & 18.43 & 273.28 & 46.82 \\
\hline & PO & 17.76 & 2.35 & 15.41 & 320.74 & 42.15 \\
\hline \multirow[t]{4}{*}{ V2 } & P1 & 18.70 & 2.42 & 16.29 & 343.02 & 49.37 \\
\hline & P2 & 18.85 & 2.67 & 16.17 & 351.79 & 54.07 \\
\hline & P3 & 18.86 & 2.95 & 15.91 & 357.22 & 59.25 \\
\hline & PO & 18.86 & 1.91 & 16.95 & 276.11 & 43.6 \\
\hline \multirow[t]{4}{*}{ V3 } & P1 & 19.74 & 2.18 & 17.55 & 298.71 & 51.55 \\
\hline & P2 & 20.70 & 2.26 & 18.44 & 312.88 & 58.75 \\
\hline & P3 & 20.62 & 2.91 & 17.71 & 320.72 & 56.78 \\
\hline & LSD at $5 \%$ & 0.17 & 0.08 & 0.15 & 2.26 & 0.79 \\
\hline
\end{tabular}


Foliar application of garlic extract, ascorbic acid or nicotinamide caused significant increases in total carbohydrates\%, total soluble sugars (TSS), polysaccharides\%, free amino acids and proline of faba bean plants. Spraying with ascorbic acid gave the best values in previous characters except for total soluble sugars.

P0 = spraying with tap water, P1 = foliar application with garlic extract at (5\%), P2 = foliar application with ascorbic acid at $200 \mathrm{ppm}$ and P1 = foliar application with nicotinamide at $50 \mathrm{ppm}$

\section{Discussion}

\section{Effect of cultivars}

The obtained data showed the significant effect of cultivars on different growth parameters (Table 2), yield and yield components of faba bean plant (Table 3), photosynthetic pigments (Chlo a, Chlo b and total pigments), indole acetic acid (IAA), phenolic contents (Table 4), carbohydrate fractions, free amino acids and proline (Table 5). Nubaria-1 cultivar gave the highest values in all growth and yield parameters compared with the other two cultivars. The superiority of Nubaria-1 cultivar for yield and its components might be due to the highest values of photosynthetic pigments. These increases might be due to the increased rate of quenching of chlorophyll fluorescence, which markedly increased plant biomass, and this steady state was greater than the other two cultivars. Moreover, the superiority of this cultivar might be due to the superiority in plant height, weight of plant, number of pods/plant, seed yield/plant and seed yield/hectare. These obtained results are in conformity with those obtained earlier (Osman et al.,2010, Bakry et al. 2011 , Khattab et al., 2015 and Abou-El-Seba et al. 2016), and they showed that faba bean cultivars varied significantly on plant height, weight/plant (g), number of pods/plant, 100-seed weight (g), seed yield/plant and seed yield (kg/hectare) during the two growing seasons. Also, Bakhoum et al. (2019), Dawood et al. (2019) and El-Bassiouny et al. (2020) confirmed this result on soybean, flax and wheat plants. These differences in morphological characters especially plant height among cultivars of faba bean might be due to genetically differences, difference in origin, growth habit and the environmental conditions of investigated cultivars. These differences observed in plants are either those treated with tap water (control) or those treated with garlic extract, ascorbic acid and nicotinamide.

Data presented in Tables 2 and 3 show the promotive effect of different treatments (garlic extract, ascorbic acid and nicotinamide) on growth parameters, yield and its components of faba bean cultivars. The results also indicate an increase in photosynthetic pigment contents.
This growth improvement in faba cultivars can be established by the fact that garlic extracts contain various growth-promoting compounds such as starch and vitamins and organosulphur compounds such as allicin and diallyl disulphide (Puvača et al. 2014 and Martins et al. 2016). However, in the current findings, there seems to be a strong correlation between the morphological indices and the developmental aspects such as chlorophyll or IAA contents. Similar results were obtained by Mady (2009) on Majorana hortensis and Salvia officinalis. Likewise, Hanafy et al. (2012) reported that the highest values of plant height, stem diameter, dry weight of leaves/plant, leaf area, total carbohydrates and $\mathrm{N}$ contents in Schefflera arboricola were obtained with garlic extract. Moreover, Sikandar et al. (2018) reported that garlic extract treatment increased growth parameters of pepper plant. Osman et al. (2014) on sunflower plant, Gul et al. (2015) on Guar plant and Ahmed et al. (2016) confirmed the obtained results using ascorbic acid on chickpea plant and El-Bassiouny et al. (2017) on sunflower plant. Moreover, the positive role of ascorbic acid may be due to that ascorbic acid caused a stimulate influencing on many physiological processes, such as stimulate respiration activities, cell division and many enzymes activities, as reported by Zewail (2007), and its important role of regulation of photosynthetic carbon reduction (Helsper et al., 1982). Moreover, Srivastava (1995) stated that foliar application increased photosynthetic rate, nutrient uptake from the soil to leaves and translocation of these nutrients from the leaves to seeds, thereby enhancing seed yield without spending any energy as well as without any loss in transit.

These results of nicotinamide are in agreement with those obtained by Sadak et al. (2010), Erdal et al. (2011), Sadak (2016) and Dawood et al. (2019). The stimulatory effects of nicotinamide on plant growth were found to be correlated with the increase in content and activity levels of endogenous promoters as IAA (Table 4) (Wilkins, 1989). Nicotinamide is known as a growth-regulating factor that influences many physiological processes such as biosynthesis of enzymes, nucleic acids and proteins and acts as a coenzyme (Hathout, 1995). These were further corroborated by the significantly higher levels of carbohydrates observed generally in the test plants nicotinamide treated (Sadak, 2016).

\section{Photosynthetic pigment content and some physiological aspects of faba bean}

All applied treatments caused marked increases in all components of photosynthetic pigments (Chlo a, Chlo b and total pigments), IAA, phenolics, carbohydrates constituents, free amino acids and proline contents compared with untreated control plants. The enhancement effect of different treatments (garlic 
extract, ascorbic acid or nicotinamide) on photosynthetic pigments could be the result of its effect on chlorophyll biosynthesis and protection of chloroplast and increasing photosynthetic activities. The results of garlic extract effect on the photosynthetic pigments are congruent with those obtained by Mohamed and Akladious (2014) on soybean and El-Rokiek et al. (2019) on quinoa plant. Moreover, these increases in response to garlic extract could be established by the fact that garlic extracts contain various growthpromoting compounds such as starch and vitamins and organosulphur compounds such as allicin and diallyl disulphide (Puva'ca et al. 2014 and Martins et al. 2016). However, in the current findings, there seems to be a strong correlation between the morphological indices and the developmental aspects such as chlorophyll contents. These results of ascorbic acid are in good agreement with those obtained on faba bean and sunflower plants (Sadak et al., 2010 and El-Bassiouny et al., 2017). Moreover, data indicated that nicotinamide treatment was more effective than other treatments. The induced role of nicotinamide is confirmed by Sadak et al. (2010), Abdelhamid et al. (2013) and Dawood et al. (2019) on sunflower and faba bean. Nicotinamide could protect chloroplast and its membrane and maintain its integrity and protect chloroplast from oxidative damage (Taylor et al., 1982 and Munne-Bosch et al., 2001). Different treatments caused significant increases in carbohydrate constituents, total phenolic content, proline and free amino acids relative to control (Table 5). These results could be showed by many authors El-Bassiouny et al. (2017) stated that the treatment of ascorbic acid to sunflower grass plants significantly increased the studied biochemical parameters. Dawood et al. (2019) confirmed the results of nicotinamide on faba bean plant. Robinson (1973) revealed that nicotinamide acts as a coenzyme in the enzymatic reactions of carbohydrates, fats and protein metabolism and involved in photosynthesis and respiration. These obtained results are in agreement with those of Dawood et al. (2019) in faba bean plant. Regarding phenolic contents, total phenolic contents play a significant mechanism in the regulation of plant metabolic processes and consequently of overall plant growth (Lewis and Yamamoto, 1990). Moreover, phenolic contents act as a substrate for many antioxidant enzymes, so, it mitigates stress injuries (Khattab, 2007).

\section{Conclusion}

It was concluded from the current field study that using different foliar applications is beneficial to mitigate sandy soil under a wide range of field conditions. The results of this study highlight the role of garlic extract in improving faba bean cultivars yield under sandy soil conditions which increased significantly grain yield/fed. To minimize the hazardous effects of abiotic stress on yield of faba bean cultivars, in general, garlic extract at the rate of $5 \%$ encourage the farmers to use it as a new natural and low-cost for stimulating to enhance faba bean that is mediated via improvement in yield and its components

\section{Abbreviations \\ V1: Nubaria-1; V2: Nubaria-2; V3: Giza-843; P1: Garlic extract; P2: Ascorbic acid; P3: Nicotinamide; LA: Leaf area; IAA: Indole acetic acid; TSS: Total soluble sugars}

\section{Acknowledgements}

Not applicable

\section{Authors' contributions}

MHM designed and performed the experiment and wrote and reviewed the manuscript. EAB designed and performed the experiment, performed the statistical analysis and wrote and reviewed the manuscript. MShS designed and performed the experiment, is responsible of all the physiological and biochemical analysis and also wrote and reviewed the manuscript. HHK designed the experiment and farming plants and wrote and reviewed the manuscript. All authors read and approved the final manuscript.

\section{Funding}

Not applicable

Availability of data and materials

Not applicable

Ethics approval and consent to participate

Not applicable

Consent for publication

Not applicable

\section{Competing interests}

The authors declare that they have no competing interests

\section{Author details}

${ }^{1}$ Field Crops Research Department, Agricultural and Biological Research Division, National Research Centre, 33th El- Behooth St., P.O. 12622, Giza, Egypt. ${ }^{2}$ Botany Department, Agricultural and Biological Research Division, National Research Centre, 33th El- Behooth St., P.O. 12622, Giza, Egypt.

Received: 8 November 2019 Accepted: 8 June 2020

Published online: 17 June 2020

\section{References}

Abdelhamid MT, Sadak MSH, Schmidhalter URS, El-Saady M (2013) Interactive effects of salinity stress and nicotinamide on physiological and biochemical parameters on faba bean plant. Acta Biológica Colombiana 18(3):499-510

Abou-El-Seba ShEA, Abou-Salama AM, El-Nagar GR, El-Mohsen MA, (2016) Physiological responses for growth and yield of some faba bean varieties under different plant densities. Assiut J. Agric. Sci., (47) No. (6-1) 18-33.

Ahmed MA, Shalaby MS, Sadak MS, Gamal El-Din KM, Abdel-Baky YR, Khater MA (2016) Physiological role of antioxidant in improving growth and productivity of chickpea (Cicer arietinum L.) grown under newly reclaimed sandy soil. Res J Pharm Biol Chem Sci 7(6):399-409

Alghamdi SS (2009) Chemical composition of faba bean (Vicia faba L.) genotypes under various water regimes. Pak J Nutr. 8:477-482

Bakhoum GS, Badr EA, Sadak MS, Kabesh MO, Amin Gehan A (2019) Improving growth, some biochemical aspects and yield of three cultivars of soybean plant by methionine treatment under sandy soil condition. Int J Environ Res 13(1):35-43 
Bakry BA, Elewa TA, El-Karamany MF, Zeidan MS, Tawfik MM (2011) Effect of row spacing on yield and its components of some faba bean varieties under newly reclaimed sandy soil condition. World J Agric Sci 7(1):68-72

Bates LS, Waldan RP, Teare LD (1973) Rapid determination of free proline under water stress studies. Plant Soil. 39:205-207

Chapman HD, Pratt RF (1978) Methods analysis for soil, plant and water. Univ California Div Agric Sci.:16-38

Danil AD, George CM (1972) Peach seed dormancy in relation to endogenous inhibitors and applied growth substances. J Amer Soc Hort Sci. 17:621-624

Dawood MG, Abdel-Baky YR, El-Awadi ME, Bakhoum GS, (2019) Enhancement quality and quantity of faba bean plants grown under sandy soil conditions by nicotinamide and/or humic acid application. Bulletin of the National Research Centre 43:28.

Dubois M, Gilles KA, Hamilton JK, Robers PA (1956) Colourimetric method for determination of sugars and related substances. Anal. Chem. 28:350-356

El-Bassiouny HMS, Abd El-Monem AA, Sadak MS, Badr NM (2017) Amelioration of the adverse effects of salinity stress by using ascorbic acid in sunflower cultivars. Bull NRC 41(2):233-249

El-Bassiouny HMS, Abdallah MMS, El-Enany MAM, Sadak MS (2020) Nano-zinc oxide and Arbuscular mycorrhiza effects on physiological and biochemical aspects of wheat cultivars under saline conditions. Pakistan J Biol Sci. 23:478490. https://doi.org/10.3923/pjbs.2020.478.490

El-khayat EF, Hegab MFAH, Gaaboub IA, El-Hosary Rasha A, Gouda Aml E (2015) Effect of faba bean varieties and phosphorus fertilization on the population density aphids and thrips in qalubia governorate. J Plant Prot Path 6(5):783791

El-Rokiek KG, Dawood MG, Sadak Mervat Sh, El-Awadi ME ,(2019) The effect of the natural extracts of garlic or Eucalyptus on the growth, yield and some chemical constituents in quinoa plants El-Rokiek et al. Bull Nat Res Centre, 43:119. https://doi.org/https://doi.org/10.1186/s42269-019-0161-3

El-Saadony FM, Nawar DAS, Zyada HG (2017) Effect of foliar application with salicylic acid, garlic extract and proline on growth, yield and leaf anatomy of pea (Pisum sativum L.) grown under drought stress. Middle East J Appl Sci 07(3):633-650

Gomez KA, Gomez AA (1984) Statiscal procedures for agriculture research, 2nd edn. Wiley, New York

Gul H, Ahmad R, Hamayun M (2015) Impact of exogenously applied ascorbic acid on growth, some biochemical constituents and ionic composition of guar (Cymopsis Tetragonoloba) subjected to salinity stress. Pakhtunkhwa Aust J Basic Appl Sci Life Sci. 3(1-2):22-40

Hanafy MS, Saadawy FM, Milad SMN, Ali RM (2012) Effect of some natural extracts on growth and chemical constituents of Schefflera arboricola plants. J Horticultural Sci Ornamental Plants 4(1):26-33

Hathout TA (1995) Diverse effects of uniconazole and nicotinamide on germination, growth, endogenous hormones and some enzymic activities of peas. Egypt J Physiol Sci 19:77-95

Helsper JP, Kagan J, Maynard JM, Loewas FA (1982) Ascorbic acid biosynthesis in Ochromonasdanica. Plant Physiol. 69:458-468

Hoffmann D, Jiang Q, Men A, Kinkema M, Gresshoff PM (2007) Nodulation deficiency caused by fast neutron mutagenesis of the model legume Lotus japonicus. J Plant Physiol. 164:460-469

Homme PM, Gonzalez B, Billard J (1992) Carbohydrate content, frutane and sucrose enzyme activities in roots, stubble and leaves of rye grass (Lolium perenneL.) as affected by sources /link modification after cutting. J. Plant Physiol. 140:282-291

Kasim Wedad A, Nessem Afaf A, Gaber Azza, (2017) Alleviation of drought stress in Viciafababy seed priming with ascorbic acid or extracts of garlic and carrot. The 7th Inter. Conf." Plant \& Microbial Biotech. \& their Role in the Development of the Society"pp.45 -59.

Khattab EA, El-Dewiny CY, Afifi MH, Khalifa RKM (2015) Response of some varieties of faba bean to yeast and algae and their impact on yield and its components. Middle East J Agric Res. 4(4):907-913

Khattab H (2007) Role of glutathione and polyadenylic acid on the oxidative defense systems of two different cultivars of canola seedlings grown under saline condition. Aust J Basic ApplSci 1:323-334

Lanzotti V, Scala F, Bonanomi G (2014) Compounds from Allium specieswith cytotoxic and antimicrobial activity. Phytochem Rev 13:769-791

Larsen P, Harbo A, Klungron S, Ashein TA, (1962) On the biosynthesis of some indole compounds in AcetobacterXylinum.PhysiologiaPlantarum. 15: 552-565

Lewis N, Yamamoto E (1990) Lignin: occurrence, biogenesis and biodegradation. AnnuRev Plant Physiol Plant MolBiol 41:455-496
Lichtenthaler HK, Buschmann C, (2001). Chlorophylls and carotenoids: measurement and characterization by UV-VIS spectroscopy. In: Wrolstad RE, Acree TE, An H, Decker EA, Penner MH,

Mady A, (2009) Effect of certain medicinal plant extracts on growth, yield and metabolism of some medicinal aromatic and plants. M.Sc., Al - Azher Univ .Fac. of Sci. Botany and Microbiology Dep.

Martins N, Petropoulos S, Ferreira ICFR (2016) Chemical composition and bioactive compounds of garlic (Allium sativumL.) as affected by pre- and post-harvest conditions: a review. Food Chem 211:41-50

Mohamed HI, Akladious SA (2014) Influence of garlic extract on enzymatic and non enzymatic antioxidants in soybean plants (Glycine Max) grown under drought stress. Life Sci J 11(3 s):46-58

Munne-Bosch S, Schwarz K, Algere L (2001) Water deficit in combination with high solar radiation leads to midday depression of a-tocopherol in field grown lavender (Lavandulastoechas) plants. Aust J Plant Physiol 28:315-321

Osman AA, Yagoub SO, Tut OA (2010) Performance of faba beans (Vicia fabaL.) cultivars grown in new agro-ecological regions of Sudan (South Sudan). Aust J Basic Appl Sci 4(11):5516-5521

Osman EAM, El-Galad MA, Khatab KA, MAB E-S (2014) Effect of compost rates and foliar application of ascorbic acid on yield and nutritional status of sunflower plants irrigated with saline water. Global J Sci Res. 2(6):193-200

Pekowska E, Skupień K (2009) The influence of selected agronomic practices on the yield and chemical composition of winter garlic. Vegetable Crops Res Bull 70:173-182

Pluduma-Paunina Z, Gaile BB, Balodis R (2018) Field Bean (Vicia faba L.) Yield and quality depending on some agrotechnical aspects. Agron Res 16(1):212-220

Puvača N, Ljubojević D, Lukač D, Beuković M, Kostadinović L, Teodosin S, Stanaćev V, (2014). Bioactive compounds of garlic, black pepper and hot red pepper. In Proceedings of the XVI International Symposium, "Feed Technology", Novi Sad, Serbia, 28-30 October pp. 116-122.

Sadak Mervat Sh, (2016) Physiological role of yeast extract and nicotinamide on Pisum sativum L. plants under heat stress. Int. J. Pharm Tech Res., 9(9):170178 Google Scholar.

Sadak MS, Rady M, Badr NM, Gaballah MS (2010) Increasing sunflower salt tolerance using nicotinamide and a-tocopherol. Int J Acad Res. 2(4):263-270

Sikandar H, Ahmad H, Ali M, Kashif H, Khan MA, Cheng Z, Smith F, Gilles MA, Hamilton JK (2018) Aqueous garlic extract as a plant biostimulant enhances physiology, improves crop quality and metabolite abundance, and primes the defense responses of receiver plants. Appl Sci. 8:1505. https://doi.org/10. 3390/app8091505

Singh AK, Bharati RC, Manibhushan N, Pedpati A (2013) An assessment of faba bean (Vicia faba L.) current status and future prospect. African. J Agric Res 8(55):6634-6641

Singh, AK, Bhatt, BP, (2012) Faba Bean (Vicia faba L.): A potential leguminous crop of India ISBN 978-93-5067-773-5ICAR, RC for ER, Patna, P. 518.

Srivastava HN (1995) Mineral nutrition, plant physiology, 7th edn. Pradeep Publications, Jalandhar, p 137

Taylor SE, Terry N, Huston RP (1982) Limiting factors in photosynthesis. Plant Physiol 10:1541-1543

Vartainan N, Hervochon P, Marcotte L, Larher F (1992) Proline accumulation during droughtrhizogenesis in Brassica napusvar. Oleifera Plant Physiol. 140: 623-628

Wilkins MB (1989) Advanced plant physiology. Pitman Publishing Inc, London

Yemm EW, Cocking EC (1955) The determination of amino acids with ninhydrin. Analyst. 80:209-213

Zewail YMR, (2007). Improvement of wheat productivity by using some biofertilizers and antioxidants. M.Sc. Thesi, Fac. Agric., Moshtohor, Benha Univ., Egypt.

\section{Publisher's Note}

Springer Nature remains neutral with regard to jurisdictional claims in published maps and institutional affiliations. 